\title{
Overexpression of Pim-1 in head and neck squamous cell carcinomas
}

\author{
ULF HENNING BEIER $^{1}$, JAN BERND WEISE ${ }^{2}$, MARTIN LAUDIEN ${ }^{2}$, \\ HAUKE SAUERWEIN ${ }^{3}$ and TIBOR GÖRÖGH ${ }^{2}$ \\ ${ }^{1}$ Department of Pediatrics, University of Illinois at Chicago, 840 South Wood Street, Chicago, IL 60612, USA; \\ ${ }^{2}$ Department of Otorhinolaryngology, Head and Neck Surgery, University of Schleswig-Holstein, \\ Campus Kiel, Arnold-Heller-Str. 14, D-24105 Kiel; ${ }^{3}$ Department of Visceral- and Transplantation Surgery, \\ University of Ulm, Steinhövelstrasse 9, D-89075 Ulm, Germany
}

Received January 23, 2007; Accepted March 2, 2007

\begin{abstract}
Despite ongoing developments of treatment protocols head and neck squamous cell carcinomas (HNSCC) show only marginal improvement in outcome, which has been attributed to a lack of therapy individualized to tumor biological properties. We compared mRNA expression profiles of HNSCC and normal epithelial cells using differential display to identify gene fragments showing differential expression in HNSCC cells. We identified a 127 -bp long fragment to be overexpressed in HNSCC cells that revealed a 98.4\% homology with the Pim-1 mRNA. The differential expression was confirmed by Northern hybridization. Immunohistochemistry showed overexpression of the Pim-1 protein in 98\% (41/42) of invasive HNSCC. Analysis of Pim-1 protein expression in relation to TNM stage and histological grade of the tumors exhibited no significant correlation. However, when samples of primary tumor and metastasis retrieved from the same patients $(n=26)$ were analyzed, nearly significant correlation of Pim-1 expression with histological grade was found $(\mathrm{p}=0.06)$. The high frequency of the Pim-1 expression of HNSCC of different grades and stages in conjunction with its absence in non-neoplastic head and neck squamous cell epithelium underlines the functional role of Pim-1 in molecular processes of HNSCC.
\end{abstract}

\section{Introduction}

Head and neck squamous cell carcinomas (HNSCC) are characterized by aggressive growth and early metastatic spread

Correspondence to: Dr Tibor Görögh, Section of Experimental Oncology of the Department of Otorhinolaryngology, Head and Neck Surgery, University of Schleswig-Holstein, Campus Kiel, Arnold-Heller-Str. 14, D-24105 Kiel, Germany

E-mail: gorogh@hno.uni-kiel.de

Key words: head and neck squamous cell carcinoma, Pim-1, differential gene expression
(1). Despite ongoing developments in tumor surgery as well as radio- and chemo-therapy, HNSCC survival remains largely unimproved (2). A part of this problem is thought to be the lack of individualization of radio- and chemo-therapy regimens based on tumor biological properties (3), which emphasizes the importance of ongoing molecular genetic studies to define alterations in gene expression that may potentially help to predict tumor behavior and guide therapy more effectively (4). Furthermore, alterations in gene expression are the first detectable step of malignant transformation and can therefore be visualized long before histologic or macroscopic changes become apparent, which also bears the potential of a diagnostic advantage (5). Until now, numerous genes have been associated with HNSCC, including p53, and c-myc (6,7). Differential display (DD)RTPCR is capable of assessing 95\% of the eukaryotic mRNA, and therefore suitable to distinguish benign and malignant genotypes based on their mRNA expression profiles, which allows the identification of differentially expressed gene transcripts and the subsequent isolation and sequencing of them (8). In this report we present Pim-1 overexpression in HNSCC. Pim-1 is a 5.22-kb long protooncogene located on chromosome 6p21.2 that codes for 33-kDa (cytosolic/nucleic) and 44-kDa (submembraneous) variants of an ubiquitous intracellular enzyme (EC 2.7.11.1), which are capable of serine and threonine phosphorylation $(9,10)$. The two isoforms are separated by an alternative translational initiation site (11). Recently, Chiang et al reported Pim-1 upregulation in oral cancer squamous cell cancer formation (12), suggesting an involvement in HNSCC carcinogenesis.

\section{Materials and methods}

Cell cultures. For the DDRT-PCR procedure, two wellcharacterized cell lines, i.e. University of Michigan squamous cell carcinoma (UMSCC)-10A and University of Turku squamous cell carcinoma (UTSCC)-19A were utilized. Two keratinocyte cultures derived from pharyngeal and oral mucosa were used as control. The carcinoma cells were cultivated in Dulbecco's modified Eagle's medium, supplemented with L-glutamine, $2.5 \mathrm{mg} / \mathrm{ml}$ Amphotericin B, 10\% (v/v) fetal 
bovine serum (Seromed, Berlin, Germany), $20 \mathrm{U} / \mathrm{ml}$ penicillin, and $20 \mathrm{mg} / \mathrm{ml}$ streptomycin. The normal keratinocytes were grown in serum-free medium (Promocell, Heidelberg, Germany). The $\mathrm{pH}$ of the medium was adjusted to 7.4 by adding $0.1 \mathrm{~N}$ sodium hydroxide. The cultures were incubated at $37^{\circ} \mathrm{C}$ in a $5 \% \mathrm{CO}_{2}$ humidified atmosphere.

Histology samples. Forty-two carcinoma samples were retrieved during surgery. In addition, five normal mucosa samples (three nasal mucosa and two tonsillar epithelium) were collected to serve as controls. All samples were retrieved during surgery at the Department of Otorhinolaryngology at the University of Schleswig-Holstein, Campus Kiel, Germany, following informed consent approved by the local ethics committee (AZ:D413/03). The 42 tumor samples were derived from 28 patients $(78.5 \%$ male, mean age: $67.39 \pm 9.49$ years $)$, with 19 primary tumor and 23 metastasis samples. The control samples were taken during regular surgical treatment without additional excisions. Specimen characterization and histological grading are summarized in Table I.

Isolation of total RNA. For rapid and reproducible preparation of the RNA, the TRIzol ${ }^{\circledR}$ total RNA kit (Gibco, Ingolstadt, Germany) was used according to the manufacturer's instructions. After measurement of the RNA concentration, samples were adjusted to $1 \mu \mathrm{g} / \mu 1$ for subsequent first-strand cDNA synthesis. Quantitative analysis of the mRNA content was performed by RT-PCR using glyceraldehyde-3-phosphate dehydrogenase (G3PDH) as a control.

First-strand cDNA synthesis. Total RNA was heat denaturated $\left(70^{\circ} \mathrm{C}, 10 \mathrm{~min}\right)$, chilled on ice, and subjected to oligo(dT)primed reverse transcription using a first-strand cDNA synthesis kit (Gibco). Reverse transcription was conducted with $300 \mathrm{U}$ of MMLV reverse transcriptase in the presence of $20 \mu \mathrm{M}$ $\mathrm{dNTP}$, and $2.5 \mu \mathrm{M} \mathrm{T}_{11} \mathrm{NM}$ oligonucleotide, with $\mathrm{N}$ representing any base of cytosine, guanine and adenine, and $\mathrm{M}$ representing any base of cytosine, guanine, adenine, and thymine. The reagents were treated by 37,44 and $70^{\circ} \mathrm{C}$ cycles lasting for 15,45 and $15 \mathrm{~min}$, respectively. The resulting heat denaturated single-strand cDNA was subjected to amplification.

Differential display. Complementary DNA was incubated with $0.5 \mu \mathrm{M}$ of one of the arbitrary primer set (MWG-Biotech, Ebersberg, Germany), $2.5 \mu \mathrm{M}$ of the corresponding anchored oligo(dT)-primer, 2.5 $\mu \mathrm{M}$ dNTPs, $1.5 \mu \mathrm{M} \mathrm{MgCl}_{2}, 2 \mu \mathrm{Ci}$ $\left[\alpha-{ }^{33} \mathrm{P}\right]-\mathrm{dATP}$ (Amersham, Braunschweig, Germany), and $2.5 \mathrm{U}$ Taq-polymerase in a final volume of $50 \mu 1$. Lowstringency PCR was carried out after initial heat degradation for 40 cycles at $94^{\circ} \mathrm{C}$ for $30 \mathrm{sec}, 42^{\circ} \mathrm{C}$ for $60 \mathrm{sec}$, and $72^{\circ} \mathrm{C}$ for $30 \mathrm{sec}$, with a final extension step at $72^{\circ} \mathrm{C}$ for $5 \mathrm{~min}$ (Thermocycler 9600; Perkin-Elmer, Norwalk, CN, USA). After thermocycling the samples were mixed with $11 \mu 1$ loading dye (97\% deionized formamide, $10 \mathrm{mM}$ EDTA, $0.1 \%$ xylene cyanol, $0.1 \%$ bromphenol blue) each, and incubated by $80^{\circ} \mathrm{C}$ for $2 \mathrm{~min}$. Subsequently, $5 \mu \mathrm{l}$ of the mixture was loaded on a $6 \%$ urea containing denaturizing polyacrylamide sequencing gel. Electrophoresis was carried out for $\sim 100$ min with $40 \mathrm{~W}$ constant power until the xylene dye was $\sim 1 \mathrm{~cm}$ to the bottom. After electrophoresis, the gel was dried, and autoradiographed. The orientation of the autoradiograph was provided by a marking on both the X-ray film and the paper sheet carrying the gel.

Isolation, re-amplification, and cloning of cDNA. After developing the film bands of interest were located in the gel by punching the film with a needle. The gel slices, along with the paper, were soaked in $100 \mu 1 \mathrm{H}_{2} \mathrm{O}$ for $10 \mathrm{~min}$, boiled for $15 \mathrm{~min}$, and centrifuged at $10,000 \mathrm{x} \mathrm{g}$ for $2 \mathrm{~min}$. The supernatant was transferred to a new microfuge tube, treated with $10 \mu \mathrm{l}$ of $3 \mathrm{M} \mathrm{NaOAc}, 5 \mu \mathrm{l}$ of $10 \mathrm{mg} / \mathrm{ml}$ glycogen, $450 \mu \mathrm{l}$ of $100 \%$ ethanol and incubated at $-80^{\circ} \mathrm{C}$ for $30 \mathrm{~min}$. The sample was centrifuged at $4^{\circ} \mathrm{C}$ for 10 min to sediment the DNA. After removing the supernatant, DNA was rinsed with ice-cold $85 \%$ ethanol and centrifuged again. The pellet was dissolved with $10 \mu \mathrm{l}$ of $\mathrm{H}_{2} \mathrm{O}$ and $4 \mu \mathrm{l}$ was subjected to re-amplification under the same conditions as mentioned above, except that no isotopes were added. Following routine procedures, $5 \mu 1$ of the $40 \mu 1$ re-amplified products was separated in $1 \%$ agarose gel and stained with $0.01 \%$ ethidium bromide. Purified double-stranded cDNA fragments were ligated into the pGEM-T ${ }^{\circledR}$ vector (Promega, Heidelberg, Germany), and cloned. The plasmid-DNA was extracted using the Plasmid Mini Kit (Qiagen, Hilden, Germany) for purification according to the manufacturer's instructions. The ligation was checked by restriction analysis and subsequent agarose gel electrophoresis.

Analytical high-stringency nested PCR and sequencing of the $c D N A$. The recombinant plasmids were prepared for cyclesequencing by PCR using Dye Terminator (Perkin-Elmer, Weiterstadt, Germany) in a total volume of $50 \mu 1$. The reaction mixture contained $5 \mu 110 \mathrm{X}$ buffer, $2.5 \mathrm{U}$ Taq-polymerase, $0.2 \mathrm{mM}$ of each dNTP, $1.5 \mathrm{mM} \mathrm{MgCl}_{2}$, and $0.1 \mu \mathrm{mol}$ of forward (5'-G TAA AAC GAC GGC CAG-3') and reverse (5'CAG GAA ACA GCT ATG AC-3') M13 primers (Promega) specific to the pGEM-T vector. The PCR was run for 30 cycles at $94^{\circ} \mathrm{C}$ for $45 \mathrm{sec}, 55^{\circ} \mathrm{C}$ for $30 \mathrm{sec}$, and $72^{\circ} \mathrm{C}$ for $90 \mathrm{sec}$, followed by a 3.5 -min extension at $72^{\circ} \mathrm{C}$. After PCR, the amplicons were sequenced on a DNA-sequencing apparatus ABI PRISM 310 (Applied Biosystems, Weiterstadt).

Northern hybridization. In order to substantiate the DDRTPCR findings, a confirmatory high-stringent RT-PCR with Pim-1 gene specific primers was conducted using 5'-CAA CGA CCT GCA ACG CCA C-3' as the sense and 5'-AGA GAC CCT CTG CCT GAA G-3' as the antisense primer. The probe was labeled by chemiluminescence (Boehringer, Mannheim, Germany). Subsequently, $20 \mu \mathrm{g}$ heat-denaturated RNA derived from the HNSCC samples and keratinocytes underwent Northern blotting (13). A G3PDH probe was used to enable comparison between the Pim-1 mRNA expression levels. Finally, the blots were exposed to an X-ray film (2$20 \mathrm{~min}$ ) using an intensifier screen and processed for densitometric evaluation of the signals.

Immunohistochemistry. The tissue samples mentioned above were placed in $10 \%$ neutral buffered formalin immediately after they were obtained and were allowed to fix for 24-48 h. After fixation, the samples were dehydrated and embedded 
Table I. Immunohistochemical detection of Pim-1 in head and neck carcinomas.

\begin{tabular}{|c|c|c|c|c|c|c|}
\hline $\begin{array}{l}\text { Samples } \\
\text { (no.) }\end{array}$ & $\begin{array}{c}\text { Patient sex/age } \\
\text { (years) }\end{array}$ & $\begin{array}{l}\text { Tumor } \\
\text { location }\end{array}$ & $\begin{array}{l}\text { Type of } \\
\text { lesion }\end{array}$ & $\begin{array}{c}\text { TNM at } \\
\text { diagnosis }\end{array}$ & $\begin{array}{l}\text { Histological } \\
\text { grade }^{\mathrm{a}}\end{array}$ & $\begin{array}{c}\text { Pim-1 } \\
\text { expression }\end{array}$ \\
\hline 1 & $\mathrm{M} / 64$ & Base of the tongue & Primary & T1N2bM0 & II & + \\
\hline 2 & $\mathrm{M} / 64$ & Base of the tongue & Metastasis & T1N2bM0 & II & +++ \\
\hline 3 & $\mathrm{M} / 76$ & Base of the tongue & Primary & T1N1M0 & II & + \\
\hline 4 & $\mathrm{M} / 76$ & Base of the tongue & Metastasis & T1N1M0 & I & + \\
\hline 5 & $\mathrm{M} / 81$ & Base of the tongue & Primary & T1N2bM0 & II & - \\
\hline 6 & $\mathrm{M} / 81$ & Base of the tongue & Metastasis & T1N2bM0 & II & + \\
\hline 7 & $\mathrm{M} / 57$ & Floor of the mouth & Primary & T4aN1M0 & II & +++ \\
\hline 8 & $\mathrm{M} / 57$ & Floor of the mouth & Metastasis & T4aN1M0 & II & +++ \\
\hline 9 & $\mathrm{~W} / 57$ & Larynx & Primary & $\mathrm{T} 2 \mathrm{~N} 2 \mathrm{cM} 0$ & II & ++ \\
\hline 10 & $\mathrm{~W} / 57$ & Larynx & Metastasis & $\mathrm{T} 2 \mathrm{~N} 2 \mathrm{cM} 0$ & II & ++ \\
\hline 11 & $\mathrm{~W} / 51$ & Palate & Primary & $\mathrm{T} 2 \mathrm{~N} 2 \mathrm{cM} 0$ & II & + \\
\hline 12 & $\mathrm{~W} / 51$ & Palate & Metastasis & $\mathrm{T} 2 \mathrm{~N} 2 \mathrm{cM} 0$ & II & ++ \\
\hline 13 & $\mathrm{M} / 81$ & Palatine tonsil & Primary & $\mathrm{T} 3 \mathrm{~N} 2 \mathrm{bM} 0$ & II & ++ \\
\hline 14 & $\mathrm{M} / 81$ & Palatine tonsil & Metastasis & T3N2bM0 & II & ++ \\
\hline 15 & $\mathrm{M} / 55$ & Hypopharynx & Primary & $\mathrm{T} 2 \mathrm{~N} 2 \mathrm{bM} 1$ & III & ++ \\
\hline 16 & $\mathrm{M} / 55$ & Hypopharynx & Metastasis & $\mathrm{T} 2 \mathrm{~N} 2 \mathrm{bM} 1$ & III & +++ \\
\hline 17 & $\mathrm{M} / 63$ & Larynx & Primary & T4N2cM1 & II & + \\
\hline 18 & $\mathrm{M} / 63$ & Larynx & Metastasis & T4N2cM1 & II & + \\
\hline 19 & $\mathrm{M} / 66$ & Tonsil & Primary & T2N1M0 & II & ++ \\
\hline 20 & $\mathrm{M} / 66$ & Tonsil & Metastasis & T2N1M0 & II & +++ \\
\hline 21 & $\mathrm{M} / 70$ & Base of the tongue & Primary & $\mathrm{T} 1 \mathrm{~N} 2 \mathrm{bM} 0$ & III & ++ \\
\hline 22 & $\mathrm{M} / 70$ & Base of the tongue & Metastasis & T1N2bM0 & III & +++ \\
\hline 23 & $\mathrm{M} / 80$ & Tonsil & Primary & T1N2bM0 & II & ++ \\
\hline 24 & $\mathrm{M} / 80$ & Tonsil & Metastasis & $\mathrm{T} 1 \mathrm{~N} 2 \mathrm{bM} 0$ & II & ++ \\
\hline 25 & M/69 & Parotid gand & Primary & T4N2bM0 & $\mathrm{n} / \mathrm{a}$ & +++ \\
\hline 26 & $\mathrm{M} / 69$ & Parotid gland & Metastasis & T4N2bM0 & $\mathrm{n} / \mathrm{a}$ & +++ \\
\hline 27 & $\mathrm{M} / 76$ & Floor of the mouth & Metastasis & $\mathrm{T} 3 \mathrm{~N} 2 \mathrm{cM} 0$ & II & ++ \\
\hline 28 & $\mathrm{M} / 87$ & Floor of the mouth & Metastasis & T1N1M0 & II & ++ \\
\hline 29 & $\mathrm{M} / 60$ & Tonsil & Metastasis & $\mathrm{T} 1 \mathrm{~N} 2 \mathrm{bM} 0$ & II & +++ \\
\hline 30 & $\mathrm{~W} / 75$ & Base of the tongue & Primary & $\mathrm{T} 2 \mathrm{~N} 2 \mathrm{cM} 0$ & II & ++ \\
\hline 31 & $\mathrm{~W} / 65$ & Tonsil & Primary & T1N2bM0 & II & + \\
\hline 32 & $\mathrm{~W} / 76$ & Base of the tongue & Primary & $\mathrm{T} 2 \mathrm{~N} 1 \mathrm{M} 0$ & II & + \\
\hline 33 & $\mathrm{M} / 74$ & Hypopharynx & Primary & $\mathrm{T} 4 \mathrm{~N} 2 \mathrm{bM} 0$ & III & ++ \\
\hline 34 & $\mathrm{M} / 57$ & Larynx & Primary & T2N1M0 & II & + \\
\hline 35 & $\mathrm{M} / 60$ & Hypopharynx & Primary & $\mathrm{T} 2 \mathrm{~N} 2 \mathrm{bM} 0$ & II & +++ \\
\hline 36 & $\mathrm{M} / 69$ & Parotid gland & Metastasis & T4N2bM0 & $\mathrm{n} / \mathrm{a}$ & ++ \\
\hline 37 & $\mathrm{M} / 62$ & Sinus Piriformis & Metastasis & T1N3M0 & II & ++ \\
\hline 38 & $\mathrm{~W} / 76$ & Base of the tongue & Matastasis & $\mathrm{T} 2 \mathrm{~N} 1 \mathrm{M} 0$ & II & +++ \\
\hline 39 & $\mathrm{M} / 54$ & CUP & Metastasis & TxN2bM0 & $\mathrm{n} / \mathrm{a}$ & ++ \\
\hline 40 & $\mathrm{~W} / 60$ & CUP & Metastasis & TxN2bM0 & $\mathrm{n} / \mathrm{a}$ & ++ \\
\hline 41 & $\mathrm{M} / 62$ & Tonsil & Metastasis & $\mathrm{T} 3 \mathrm{~N} 2 \mathrm{bM} 0$ & II & ++ \\
\hline 42 & $\mathrm{M} / 71$ & CUP & Metastasis & TxN3M0 & $\mathrm{n} / \mathrm{a}$ & +++ \\
\hline $43-47$ & Normal mucosa & & & & & - \\
\hline
\end{tabular}

aI, well differentiated; II, moderately differentiated; III, poorly differentiated. The expression of Pim-1 was determined by immunocytochemistry and estimated in range from - (no expression) to +++ (strong expression). CUP, carcinoma of unknown primary. n/a, not applicable. 
in methylmethacrylate plastic. After polymerization, the samples were cut on a plane right-angled to the tissue surface. Longitudinal sections of $4 \mu \mathrm{m}$ were cut with a rotary saw microtome and transferred onto a microscopic slide. For immunohistochemical examination, sections of tissue were deparaffinized in four cycles of Xylol for $10 \mathrm{~min}$ each. The samples were rehydrated in aqua dest for $10 \mathrm{~min}$. Antigen retrieval was accomplished by washing the samples with Tris-buffered saline (TBS) solution for $5 \mathrm{~min}$. Endogenous peroxidase was blocked for $30 \mathrm{~min}$ with $1 \%$ hydrogen peroxide in methanol. Non-specific immunoglobulin binding was blocked by incubation of the slides for 10 min with a $3 \%$ goat serum in TBS for $20 \mathrm{~min}$. Primary affinity purified polyclonal rabbit anti-Pim-1 antibody (Santa Cruz Biotechnology, Santa Cruz, CA, USA) was added to the slides for $60 \mathrm{~min}$ at room temperature followed by incubation with a biotin-conjugated swine anti-rabbit IgG secondary antibody (Dako, Hamburg, Germany) at room temperature for $1 \mathrm{~h}$. A labeled peroxidase complex system (ABC-Vectorstatin, Dako) was used to visualize all immune reactions. Sections were counterstained with Mayer's hematoxylin. For negative controls, the primary antibodies were replaced with homologous non-immune sera. The slides were evaluated in cooperation with the Pathology department of the University of SchleswigHolstein, Campus Kiel. To quantify the Pim-1 expression, 300 cells were examined in at least five areas at magnification $\mathrm{x} 400$ and a mean percentage of positive tumor cells was determined assigning cases to one of the four following categories: -, <5\%; I, 5-30\%; II, 31-75\%; III, >75\%. Cases with a score of - were considered as negative, cases with scores I, II, III were considered as positive.

Statistical analysis. All data assembled in this study were analyzed using SPSS 12.0 (Statistical Package for the Social Sciences, SPSS Inc., Chicago, IL). All results were tested on normal distribution using the Kolmogorov-Smirnov test. All normally distributed data are displayed as mean \pm standard deviation, the non-normally distributed are displayed as median with 1st and 3rd quartile. We analyzed correlations between Pim-1 expression on the histology slides with TNM stage and histologic grade. If the data followed normal distribution, Pearson's bivariate correlation analysis was applied, if otherwise, Spearman's correlation analysis was used. A p $<0.05$ was considered significant.

\section{Results}

Differential expression of the Pim-1 mRNA. Three downstream primers (D2, D3, D4) were combined with 26 upstream primers, leading to 78 PCR investigations. The amplification products were separated by polyacrylamide gel electrophoresis, displaying 80-100 individual cDNA bands per line, which in vast majority were identical in expression pattern. However, the combination of the D4 (5'-TTT TTT TTT TT AG-3') and U23 (5'-GAT CTG ACT G-3') primers showed reproducible differences between the cell lines' expression patterns, suggesting the presence of a differentially expressed gene (Fig. 1A). The bands of interest were marked on the dried polyacrylamide gel with the help of an X-ray. Subsequently the fragment was recovered from the gel, re-amplified showing

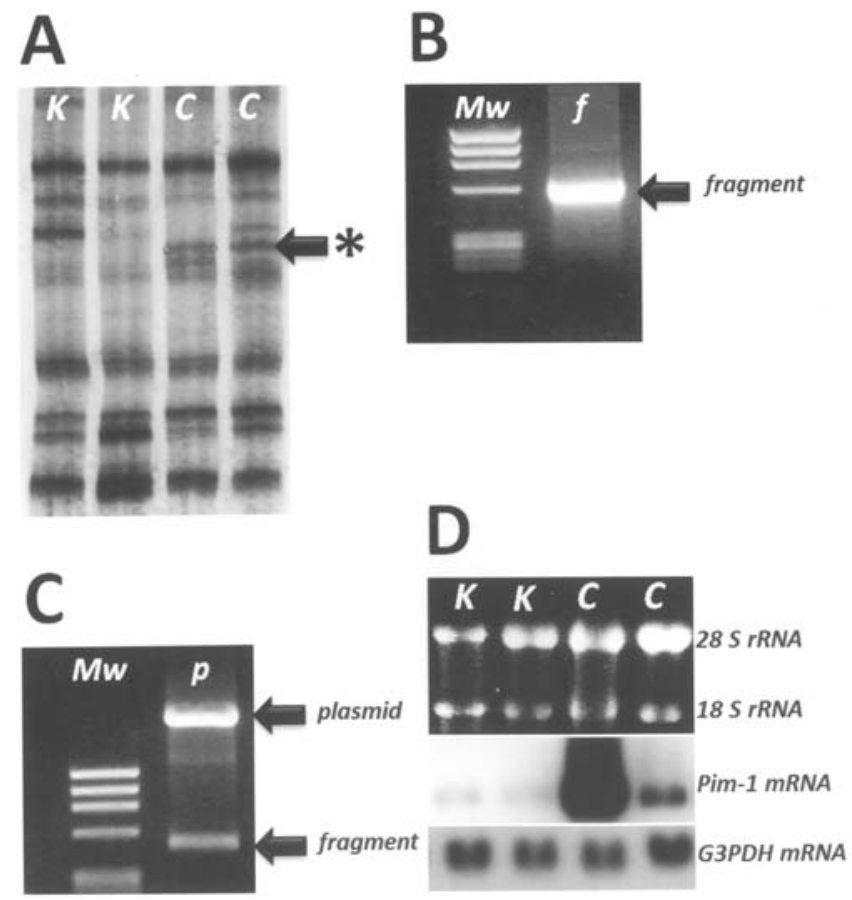

Figure 1. (A) Comparative analysis of mRNA differential display. Total RNA from two independent normal upper aerodigestive tract mucosal keratinocytes $(\mathrm{K})$ and SCC cell lines (C) were reversely transcribed. After RT-PCR, $\left[{ }^{33} \mathrm{P}\right]$-labeled amplicons were subjected to denaturing polyacrylamide gel electrophoresis. The gel was dried and fingerprints were visualized by autoradiography. The displayed area depicts a fragment strongly overexpressed in SCC cells. (B-D) Following band excision, the gene fragment was reamplified (B), cloned and stained with ethidium bromide (C). (D) Northern hybridization showing the overexpression of Pim-1 mRNA in the two laryngeal squamous cell carcinoma cell lines $(C)$ in contrast to benign epithelial keratinocytes $(K)$. The samples were simultaneously hybridized with a glyceraldehyde-3-phosphate-dehydrogenase probe to verify equal amounts of mRNA.

an 130-bp long fragment and cloned (Fig. 1B and C). After sequencing the cloned fragment the sequence was subjected to GenBank database searching with query sequences. A $98 \%$ identity with bases $5828-5955$ belonging to the last exon (exon 6) of the human Pim-1 oncogene was found (Fig. 2), with one additional guanine and adenine at positions 5854/5855 and 5867/5868 respectively.

Ligation, transformation and cloning. The amplified fragment was successfully ligated into a pGEM-T vector carrying ampicillin resistance and transformed into competent Escherichia coli. The Escherichia coli were cultivated on an ampicillin bearing medium, thereby selecting these cells with successful transformation. Ligation was verified via galactosidase inactivation in the plasmid. Following bacterial replication, the competent cells were lysed and the plasmids carrying the fragment isolated. Subsequently, the replicated fragment was cut out of the plasmid by restriction endonucleases and separated from the plasmid by agarose gel electrophoresis (Fig. 1C).

Sequence analysis. For sequence analysis, competent cells were harvested and the plasmids isolated. The plasmids were then processed with vector-specific upstream and downstream primers. Sequence analysis of both amplicons in 5'-3' as well 


$\begin{array}{lllllll}1-60 & \text { CCCGAGAGGA } & \text { GTCGGTGGCA } & \text { GCGGCGGCGG } & \text { CGGGACCGGC } & \text { AGCAGCAGCA } & \text { GCAGCAGCAG } \\ 61-2400 & (\ldots) & & & & \\ 2401-2460 & \text { TACTMACCCA } & \text { GGTGGGTCCC } & \text { GGCTCTGTGG } & \text { GTGATGGGGA } & \text { GGGGCATTGC } & \text { TGACTGTGTA } \\ 2461-2520 & \text { TATAGGATAA } & \text { TTATGAAAAG } & \text { CAGTTCTGGA } & \text { TGGTGTGCCT } & \text { TCCAGATCCT } & \text { CTCTGGGGCT } \\ 2525-2580 & \text { GTGTTTTGAG } & \text { CAGCAGGTAG } & \text { CCTGCTGGTT } & \text { TTATCTGAGT } & \text { GAAATACTGT } & \text { ACAGGGGAAT } \\ 2581-2640 & \text { AAAAGAGATC } & \text { TTATTTTTT } & \text { TTTTATACTT } & \text { GGCGTTTTTT } & \text { GAATAAAAAC } & \text { CTTTTGTCTT } \\ 2641-2684 & \text { AAAAAAAAAA } & \text { AAAAAAAAAA } & \text { AAAAAAAAAA } & \text { AAAAAAAAAA } & \text { AAAA } & \end{array}$

Figure 2. Sequence of homo sapiens pim-1 oncogene mRNA (2684 bp, accession number: NM_002648). The fragment identified by differential display is shown in boldface, the annealing sites of the D4 and U23 primers are underlined.

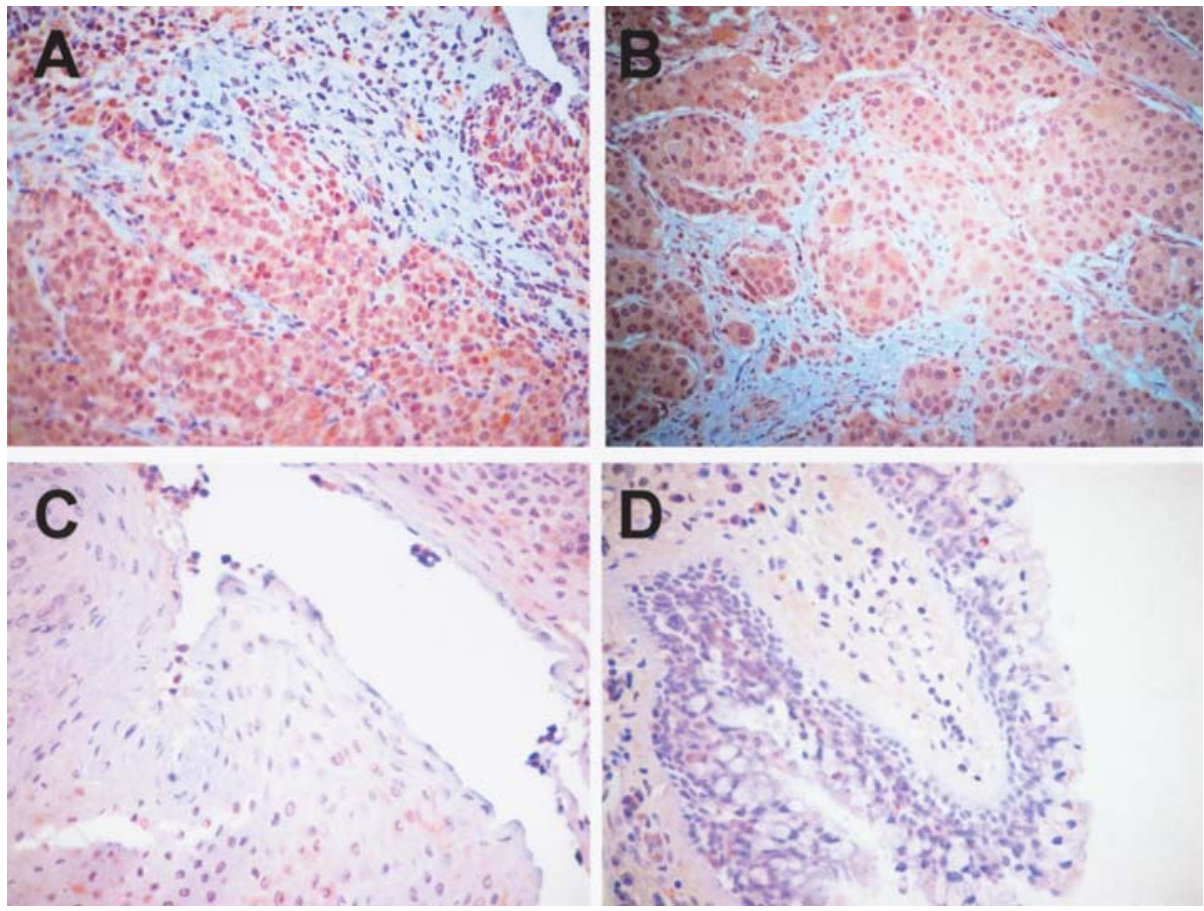

Figure 3. Immunoperoxidase staining of HNSCC biopsies using anti-Pim-1 antibody. (A and B) Primary tumor (hypopharynx) and metastasis, respectively. (C) Tonsillar epithelium and (D) normal nasal mucosa. Both carcinoma biopsies show intense cytoplasmic reactivity with the antibody whereas there is very little or no apparent antigen expression in the normal biopsies (x200).

as $3^{\prime}-5$ ' direction identified a 127 -bp long fragment that revealed a 98.4\% homology with the Pim-1 mRNA (Fig. 2). The human Pim-1 gene consists of 6113 bp. We identified our fragment in between base 5828 and 5955, with one additional guanine (5854/5855) and one additional arginine (5867/5868).

Northern hybridization. In order to substantiate DDRT-PCR findings, a confirmatory high-stringent RT-PCR with Pim-1 specific oligonucleotides was carried out. The gene deduced amplification product was 729 -bp long, matching to the positions 73-802 of the Pim-1 mRNA. The overexpression of Pim-1-mRNA could be verified in HNSCC cells by using Northern analysis. The distinct band of $2.5 \mathrm{~kb}$ that corresponds to the estimated size of Pim-1-mRNA (2521 bp) clearly exhibited a higher excess in carcinoma cells as compared with normal epithelial cells (Fig. 1D).

Pim-1 protein expression. To assess the expression of the Pim-1 protein, immunohistochemistry was performed, using antibody raised against amino acids 271-313 mapping at the C-terminus of Pim-1 of human origin with both 33- and 44-kDa isoforms (Fig. 3). Strong expression of Pim-1 in primary tumors (Fig. 3A) and metastases (Fig. 3B) was shown, the staining reaction being diffuse cytoplasmic. Normal non-neoplastic tonsillar epithelium (Fig. 3C) and nasal mucosa (Fig. 3D) exhibited virtually no reactivity with the Pim-1 antibody. Of the 42 tumor biopsies representing different locations and tumor stages, immunohistochemistry showed Pim-1 expression in 41 (98\%) invasive HNSCC. The correlation between TNM and Pim- 1 expression was not significant $(\mathrm{p}=0.15$ for tumor stage; $\mathrm{p}=0.70$ for nodal stage; and $\mathrm{p}=0.52$ for metastasis stage, respectively). Similarly, Pim-1 expression appeared unrelated to the degree of tumor differentiation $(\mathrm{p}=0.08)$. In contrast, nearly significant correlation of Pim- 1 expression with histological grade was found $(\mathrm{p}=0.06)$ when samples of primary tumor and metastasis retrieved from the same patients were analyzed (Table II).

\section{Discussion}

The Pim-1 oncogene was originally identified as a common integration site for Moloney murine leukemia virus (14), and 
Table II. Correlation of Pim-1 expression with clinical parameters.

\begin{tabular}{|c|c|c|c|c|c|c|c|c|c|c|c|c|}
\hline & \multicolumn{3}{|c|}{ Tumor stage } & \multicolumn{3}{|c|}{ Nodal stage } & \multicolumn{3}{|c|}{ Metastatic stage } & \multicolumn{3}{|c|}{ Histological grading } \\
\hline & $\mathrm{PC}$ & $\mathrm{p}$ & $\mathrm{N}$ & $\mathrm{PC}$ & $\mathrm{p}$ & $\mathrm{N}$ & $\mathrm{PC}$ & $\mathrm{p}$ & $\mathrm{N}$ & $\mathrm{PC}$ & $\mathrm{p}$ & $\mathrm{N}$ \\
\hline $\begin{array}{l}\text { Pim- } 1 \text { expression } \\
\text { (all samples } n=42 \text { ) }\end{array}$ & +0.23 & 0.15 & 39 & +0.06 & 0.70 & 42 & -0.10 & 0.52 & 42 & +0.30 & 0.08 & 36 \\
\hline $\begin{array}{l}\text { Pim-1 expression } \\
\text { (subgroup } n=26)\end{array}$ & +0.32 & 0.12 & 26 & -0.32 & 0.53 & 26 & -0.11 & 0.61 & 26 & +0.39 & 0.06 & 24 \\
\hline
\end{tabular}

PC, Pearson's correlation coefficient; p, p-value; N, number of pairs.

was shown to efficiently cooperate with c-myc, N-myc, or bcl-2 genes in lymphomagenesis (15). Pim-1 is involved in normal lymphocyte activation and proliferation (16), and has been described to inhibit apoptosis (17), which has given support to the potential involvement of Pim-1 in carcinogenesis, which has been well studied especially in prostate cancer (18) and lymphomas (19).

Pim-1 regulation. The Pim-1 enzyme is controlled on transcriptional and posttranscriptional, as well as on translational and posttranslational levels (20). Nagarajan et al suggested that Pim-1 mRNA expression is induced by reciprocal translocations involving 6p21 (21), which is consistent with the observation that deletions of the short arm of chromosome 6 are frequently associated with lymphatic malignancies (22). However, this approach is controversial, as von Lindern et al showed that induction of Pim-1 expression is not mediated via translocation as it is still located on chromosome 6 with the breaking point being $165 \mathrm{~kb}$ away (23). The Pim-1 promoter contains no TATA and CAAT binding sites, but numerous GC boxes (24). Hoover et al showed that in T lymphocytes, overexpressed Pim-1 mRNA did not correlate with the protein level due to a 400-bp non-translating GC-rich region within the mRNA (25). Our results confirmed however, that increased Pim-1 mRNA expression was associated with an increased Pim-1 protein production.

Mechanisms of Pim-1-mediated carcinogenesis. Among the reported mechanisms of Pim-1-mediated cellular proliferation, the promotion of the complex formation between NuMA, HP1ß, dynein and dynactin is necessary for mitosis (26). Furthermore, Pim-1 directly binds to a specific domain of tyrosine kinase and such interaction modulates the tyrosine kinase activity possibly by competing with the tumor suppressor p53 (27). A major area of interest is the influence of Pim- 1 on apoptosis. Wang et al showed that Pim-1 functions to prevent premature onset of apoptosis in myeloid cell differentiation due to tyrosine phosphatase inactivation (20). Furthermore, Pircher et al showed suppression of Co60- and adriamycininduced apoptosis in murine hematopoetic cells (28). Rahman et al demonstrated that Pim-1 expression is interleukin-6 dependent; once interleukin-6 is withdrawn, Pim-1 expression declines, leading to a higher rate of apoptosis in mouse B-cell hybridoma cells (29). Another pathway considered was facilitation of tumor invasiveness and metastasis formation. Our own data did not show significant associations with either TNM state or the histological grade, and therefore does not support such an association, which is consistent with the literature on prostate cancer (18). In consideration of our own data and the present literature, increased Pim-1 transcription and translation can fit well into several molecular cancer hallmarks proposed by Hanahan and Weinberg (30), namely apoptosis evasion, resistance to growth inhibition, and growth promotion. Therefore, overexpressed Pim-1 might lead to malignant phenotypes via these mechanisms in HNSCC.

\section{Acknowledgements}

We thank Drs Grenmann and Carry for providing the HNSCC cell lines. This study was supported in part by grants from the IZKF University of Schleswig-Holstein, Campus Kiel.

\section{References}

1. Werner JA: The current status of the care for lymph drainage in malignant head-neck tumors. Laryngorhinootologie 76: 643-644, 1997.

2. Argiris A: Update on chemoradiotherapy for head and neck cancer. Curr Opin Oncol 14: 323-329, 2002.

3. Akervall J: Gene profiling in squamous cell carcinoma of the head and neck. Cancer Metastasis Rev 24: 87-94, 2005.

4. Hardisson D: Molecular pathogenesis of head and neck squamous cell carcinoma. Eur Arch Otorhinolaryngol 260: 502-508, 2003.

5. Brennan JA, Boyle JO, Koch WM, Goodman SN, Hruban RH, Eby YJ, Couch MJ, Forastiere AA and Sidransky D: Association between cigarette smoking and mutation of the p53 gene in squamous-cell carcinoma of the head and neck. N Engl J Med 332: 712-717, 1995.

6. Dolcetti R, Doglioni C, Maestro R, Gasparotto D, Barzan L, Pastore A, Romanelli M and Boiocchi M: p53 over-expression is an early event in the development of human squamous-cell carcinoma of the larynx: genetic and prognostic implications. Int J Cancer 52: 178-182, 1992.

7. Fan CS, Wong N, Leung SF, To KF, Lo KW, Lee SW, Mok TS, Johnson PJ and Huang DP: Frequent c-myc and Int-2 overrepresentations in nasopharyngeal carcinoma. Hum Pathol 31: 169-178, 2000.

8. Bauer D, Muller H, Reich J, Riedel H, Ahrenkiel V, Warthoe P and Strauss M: Identification of differentially expressed mRNA species by an improved display technique (DDRT-PCR). Nucleic Acids Res 21: 4272-4280, 1993.

9. Hoover D, Friedmann M, Reeves R and Magnuson NS: Recombinant human pim-1 protein exhibits serine/threonine kinase activity. J Biol Chem 266: 14018-14023, 1991. 
10. Reeves R, Spies GA, Kiefer M, Barr PJ and Power M: Primary structure of the putative human oncogene, pim-1. Gene 90 : 303-307, 1990.

11. Saris CJ, Domen J and Berns A: The pim-1 oncogene encodes two related protein-serine/threonine kinases by alternative initiation at AUG and CUG. EMBO J 10: 655-664, 1991.

12. Chiang WF, Yen CY, Lin CN, Liaw GA, Chiu CT, Hsia YJ and Liu SY: Up-regulation of a serine-threonine kinase protooncogene Pim-1 in oral squamous cell carcinoma. Int J Oral Maxillofac Surg 35: 740-745, 2006.

13. Sambrook J, Fritsch EF and Maniatis T: Molecular cloning. A laboratory manual. 2nd edition. Cold Spring Harbor Laboratory Press, Cold Spring Harbor, NY, 1989.

14. Cuypers HT, Selten G, Quint W, Zijlstra M, Maandag ER, Boelens W, van Wezenbeek P, Melief C and Berns A: Murine leukemia virus-induced T-cell lymphomagenesis: integration of proviruses in a distinct chromosomal region. Cell 37: 141-150, 1984.

15. Van Lohuizen M, Verbeek S, Krimpenfort P, Domen J, Saris C, Radaszkiewicz T and Berns A: Predisposition to lymphomagenesis in pim-1 transgenic mice: cooperation with c-myc and $\mathrm{N}$-myc in murine leukemia virus-induced tumors. Cell 56: 673-682, 1989.

16. Wingett D, Reeves R and Magnuson NS: Stability changes in pim-1 proto-oncogene mRNA after mitogen stimulation of normal lymphocytes. J Immunol 147: 3653-3659, 1991

17. Lilly M, Sandholm J, Cooper JJ, Koskinen PJ and Kraft A: The PIM-1 serine kinase prolongs survival and inhibits apoptosisrelated mitochondrial dysfunction in part through a bcl-2dependent pathway. Oncogene 18: 4022-4031, 1999.

18. Cibull TL, Jones TD, Li L, Eble JN, Ann Baldridge L, Malott SR, Luo Y and Cheng L: Overexpression of Pim-1 during progression of prostatic adenocarcinoma. J Clin Pathol 59: 285-288, 2006.

19. Rubenstein JL, Fridlyand J, Shen A, Aldape K, Ginzinger D, Batchelor T, Treseler P, Berger M, McDermott M, Prados M, Karch J, Okada C, Hyun W, Parikh S, Haqq C and Shuman M: Gene expression and angiotropism in primary CNS lymphoma. Blood 107: 3716-3723, 2006.
20. Wang Z, Bhattacharya N, Meyer MK, Seimiya H, Tsuruo T, Tonani JA and Magnuson NS: Pim-1 negatively regulates the activity of PTP-U2S phosphatase and influences terminal differentiation and apoptosis of monoblastoid leukemia cells. Arch Biochem Biophys 390: 9-18, 2001.

21. Nagarajan L, Louie E, Tsujimoto Y, ar-Rushdi A, Huebner K and Croce CM: Localization of the human pim oncogene (PIM) to a region of chromosome 6 involved in translocations in acute leukemias. Proc Natl Acad Sci USA 83: 2556-2560, 1986.

22. Rickert CH, Dockhorn-Dworniczak B, Simon R and Paulus W: Chromosomal imbalances in primary lymphomas of the central nervous system. Am J Pathol 155: 1445-1451, 1999.

23. Von Lindern M, van Agthoven T, Hagemeijer A, Adriaansen $H$ and Grosveld G: The human pim-1 gene is not directly activated by the translocation $(6 ; 9)$ in acute nonlymphocytic leukemia. Oncogene 4: 75-79, 1989.

24. Meeker TC, Nagarajan L, ar-Rushdi A, Rovera G, Huebner K and Croce CM: Characterization of the human PIM-1 gene: a putative proto-oncogene coding for a tissue specific member of the protein kinase family. Oncogene Res 1: 87-101, 1987.

25. Hoover DS, Wingett DG, Zhang J, Reeves R and Magnuson NS Pim-1 protein expression is regulated by its $5^{\prime}$-untranslated region and translation initiation factor elF-4E. Cell Growth Differ 8 : 1371-1380, 1997.

26. Bhattacharya N, Wang Z, Davitt C, McKenzie IF, Xing PX and Magnuson NS: Pim-1 associates with protein complexes necessary for mitosis. Chromosoma 111: 80-95, 2002.

27. Xie Y, Xu K, Dai B, Guo Z, Jiang T, Chen H and Qiu Y: The $44 \mathrm{kDa}$ Pim-1 kinase directly interacts with tyrosine kinase Etk/BMX and protects human prostate cancer cells from apoptosis induced by chemotherapeutic drugs. Oncogene 25: 70-78, 2006.

28. Pircher TJ, Zhao S, Geiger JN, Joneja B and Wojchowski DM Pim-1 kinase protects hematopoietic FDC cells from genotoxininduced death. Oncogene 19: 3684-3692, 2000.

29. Rahman Z, Yoshikawa H, Nakajima Y and Tasaka K: Downregulation of Pim-1 and Bcl-2 is accompanied with apoptosis of interleukin-6-depleted mouse B-cell hybridoma 7TD1 cells. Immunol Lett 75: 199-208, 2001.

30. Hanahan D and Weinberg RA: The hallmarks of cancer. Cell 100: 57-70, 2000. 